\title{
Restoration, Reconstruction and Union: memories of home in the stratiot poetry of Antonio Molino ${ }^{1}$
}

\begin{abstract}
The paper explores the notion of home in the stratiot poetry authored by $16^{\text {th }}$-century Venetian comedy author and composer Antonio Molino. Rooted in the life of the stratiots and their struggles against the Ottomans, this poetry allegedly reflects the diasporic memory of Greek stratiots, although it is apparently framed by the genre and preferences of Molino's theatre audience. By analysing the memoryscape of notions of home which Molino linked to the Greek stratiots of his time, the paper reveals that his poetry projects, in fact, were the more tangible political ambitions of the Republic of Venice to convert the stratiots from Orthodox Christianity to Roman Catholicism, reinforce their Venetian identity and use their memory in its own aspiration to the Byzantine imperial legacy - all highly topical on the eve of the Venetian conflict with the Ottomans over Cyprus (1571-1573).
\end{abstract}

Stratiots were military groups (infantry, light cavalry, but also naval troops) formed of émigré soldiers who originated from Greece and other parts of the postByzantine Balkans, and were deployed as mercenaries or regular soldiers by the Republic of Venice, the king of Naples and other European rulers between the $15^{\text {th }}$ and the $18^{\text {th }}$ centuries. ${ }^{2}$ Modern scholarship is generally familiar with their military capacity and campaigns, but also the literary work that reflects the reception of the stratiots and their tradition in the Apennines and elsewhere in the European West (letteratura stratiotescha). ${ }^{3}$ Some of these literary pieces have taken the form of verse and represent the "poetry of exile" inspired by these soldiers' individual,

This paper is an updated version of my communication presented at the International Medieval Congress in Leeds in 2018, and it represents the part of my research project MIGWEB: A Comparative Diachronic Analysis of Post-Byzantine Networks in Early Modern Europe (15 $5^{\text {th }}-18^{\text {th }} \mathrm{c}$.), done at the Royal Holloway University of London and funded by the European Union's Horizon 2020 research and innovation program under Marie Skłodowska Curie Grant Agreement No. 747857.

2 ROGERS 1995; TURNBULL, 2006. The peak of stratiots' fame was in the $16^{\text {th }}$ century, when they were recorded as active in Venetian territories, the Kingdom of Naples, the German lands, France, Spain and even England under Henry VIII.

3 ROSSI 1888: XXXII, n. 1; KOLYVA 1973: 138-162; SATHAS 1986; TUCCI 1987: 86-88; PLOUMIDES 1995: 229-233; PETTA 1996; BUGH 32: 81-96; BIRTACHAS 2012. 
direct memories of conflict and migration, but also by diverse immediate perceptions of their deeds generated by the milieus in their host communities. Among such works we find the elegant rhymes of Greek Humanist Michael Tarchaniota Marullus (b. ca. 1458-1500), the heroic poems of Tsanes Koronaios which glorify the famed Albanian commander of the Venetian army, Mercurio Bua (fl. late $15^{\text {th }} /$ early $16^{\text {th }} \mathrm{c}$.), the comprehensive cycles of the oral tradition of Albanian stratiots in Southern Italy and Slavic peasant-fighters from Venetian Dalmatia (uskoci) but also plays by Italian comedy writers that utilised the stratiot tradition to win the interest of their popular Italian audiences. ${ }^{4}$

Highly diverse in their structure, tone and language, and hardly comparable from the standpoints of their authors' intentions and intended audiences, these pieces of poetry still have one thing in common: they all represent stratiots as adventurer warriors especially hostile to the Muslim "Turks." This image is rooted in the fall of the Byzantine East to the Ottomans (1453) and the frequent calls of the soldiers to "avenge" the alleged loss of their native land. This image is, however, somewhat challenged by the fact that in reality many of the stratiots were documented as still residing in the Greek territories that, at the time, were formally subject to the Republic of Venice, which further suggests that the "diasporic" memory of these accounts, in addition to their shaping of the stratiot image by the poetic genres, must have been subject to certain modifications that reflected their actual statuses, as well as the wider socio-cultural, or even political projections of their Italian hosts. In order to learn more about this process, in this paper I shall survey the mnemonic tools that were used in stratiot poetry to present the character and

$4 \quad$ A part of Marullus' work, De principum institutione, was published by SATHAS VIII: 592608; Joannes Gemistos' Protrepticon et Prognosticon to Pope Leo X was published in SATHAS VIII: 545-592; Koronaios, ed. HOPF: 367-370. For a scholarly interpretation of Marullus' work, HASKELL 1999: 109-136; LAMMERS 2015: 206-232. Recently on Gemistos, LAMMERS 2015: 233-269. For the oral tradition of Albanian and Slavic soldiers, SCURA: 1912 and BRACEWELL: 1992. Apart from Molino's works, stratiots were in the focus of interest of several Venetian writers, such as comedy writer Andrea Calmo (Las Spagnolas, 1549) or madrigalist Ivo de Vento (Libro delle gregesche/Battaglia stratiotescha, Cando la bun caval, 1564, no. 38). These authors, apart from their immediate perceptions and experiences with the stratiots, also largely exploited popular negative stereotypes of the Greeks, some of which had been in wider circulation since the Latin Conquest of Constantinople (1204), cf. MADDEN 2008; ARBEL, HAMILTON AND JACOBY 1989. These stereotypes highlighted the Greeks' reported capriciousness, soft/feminine and "cunning" character, and their "unnatural" appearance (as deduced from their clothes, stature, and behaviour), and were especially popular in Venice and Naples, which had direct links with Greece, hence influencing certain genres of the local popular poetry, such as the maccaroni verses. Despite their mocking tone and common negative stereotypical representation as a different Other, the image of the Greek stratiots formulated by Italian authors projected important pieces of information about the creation of popular lore about these soldiers and their traditions.

5 Balzeletta, SATHAS VIII, no. 28, 463. 
deeds of these soldiers, specifically focusing on the work of Italian comedy writer Antonio Molino, nick-named Burchiella (ca. 1495-ca. 1571). ${ }^{6}$ In this, my attention shall focus on the "places of memory" that he highlighted in his verse-remarkable details of the poetry's content that show how the stratiot past and present were constructed. ${ }^{7}$ Molino was a Venetian merchant who turned to comedy writing and composition in his later years, after the time he had spent in Greece. There, he had a chance to establish direct contacts with certain prominent Greek stratiots, which allowed him to fuse into his songs the direct reminiscences he must have heard from some of these soldiers with the expectations of the Venetian masses who visited his theatre (Academia Musica). ${ }^{8}$

Certainly the most visible places of memory recalled by the stratiot poetry circulated in the Apennines during the $16^{\text {th }}$ century are the notions of home. ${ }^{9}$ Interestingly, these notions mix two different types of home - the genuine homes of

$\overline{6}$ While most of these works were first published in the $16^{\text {th }} \mathrm{c}$, their integral modern (albeit occasionally erroneous and romanced) publication was made by SATHAS 1888-1890: vols. VII, VIII, IX. For more recent editions of some of them, CISILINO 1974. The central poem of this oeuvre is a poem entitled I fatti e prodezze di Manoli Blessi that consists of 12 "songs"/ canti, introduced (possibly partly authored too) by Lodovico Dolce (1561, see SATHAS VIII: 471-472), which Molino intended for a musical performance in the theatre (e.g. I fatti e prodezze, canto 1, no. 1, 473: trombizo e canto); for the reception of Molino's work by other Italian composers, cf. BIRTACHAS 2012: 130-131, esp. n. 28. Other songs linked to Molino are Balzeletta (SATHAS VIII: 461-465), the Sopra la pressa de Margaritin (allegedly taken from larger work kept in Venice's Marciana Library, cf. SATHAS VIII: 461-470), La pressa di Nicosia (1570) (SATHAS IX: 262-280) and la Barzelletta de quattro compagni Strathiotti de Albania (SATHAS VII: 236 - 261), accounting the initial events of Venice's conflict with the Ottomans over Cyprus (1571-1573).

7 A place of memory is understood here as part of a specific émigré "memoryscape" - a set of memories of time and space that commonly circulated (orally) among the stratiots and their host surroundings, not necessarily reflecting their individual internal experiences, cf. FREIST 2013: 203-221.

8 COUTELLE 1971; CORTELAZZO 1972: 51-64; The language of Molino's songs is gregescho, a hybrid form that imitated Greek demotica, dialects spoken in the Eastern Adriatic and the local vulgar Venetian expression, largely mixed by Greek émigrés in the Apennine Peninsula. This misled the songs' $19^{\text {th }}$-century editor, K. N. Sathas, to assume that their protagonist, a remarkable character of Molino's poems named Manolis Blessis, was their author and that his account was only "pasted" by Molino into his plays. For recent corrections of this view that convincingly propose Molino as the songs' actual author, see LAUXTERMANN 2013: 189-207. In his works, most apparently, I fatti e prodezze di Manolis Blesis, Molino openly mocked the stratiots, but also demonstrated a fair knowledge of their habits, which suggests that he must have had immediate contacts with some of them during his mercantile travels to Greece (e.g. prominent stratiot Bartolommeo Minio, Venetian proveditore di stratioti in Greek Nauplion), or at least heard the local accounts on the famous $15^{\text {th }}$ century stratiot figures such as Pietro Bua, the father of the widely popular Mercurio (d. by the early 1560s). For various perceptions of Greece among Greek intellectuals and their hosts that generally circulated in the European West at the time, LAMMERS 2015.

9 ZEČEVIĆ 2016: 185-198. 
the stratiots, largely located in the Peloponnese and the Aegean, and their symbolic Home, commonly presented as their place of origin in the Byzantine Empire and Constantinople as its capital. ${ }^{10}$ This symbolic Home is imminently linked with the topos of Patria (fatherland), which, during the $16^{\text {th }}$ century, depicted the common Humanist patriotic perception of home as a place of birth and ancestry that is worth one's own bloodshed and death. ${ }^{11}$ While the "real" homes of the stratiots in Greece are rarely mentioned, and in a more-less realistic manner, ${ }^{12}$ their Home is historicised by the humanistically conceived linear accounts in which the verses narrate about a sequence of time that progressively unfolds from the "beginning" until the "end," eschatologically establishing Home as the place of the soldiers" "origin" and "final return." ${ }^{13}$ For some stratiot authors (e.g. Manilio Cabacio Rallo; the songs of Albanian soldiers from the Italian South), Home was irrevocably lost; some (e.g. Michael Tarchaniota Marullus), however, preferred to see it transformed into an asset of Latin culture, or even a still existing "living" entity, but a widely unhappy place (patria infelix) (e.g. Joannes Gemistos, Antonio Molino). ${ }^{14}$ In all of these accounts, Home was additionally historicised with laments about its occupation by the "impious" Turks, who are seen as pagans and "Patarenes," or, through the usual Humanist discourse, Herodotus' "blood-thirsty" Scythians, Turcomans, Avars, Moors and "wild beasts" because they "enslaved" the families of the stratiots and left them "trapped behind" (i.e. in the past), ${ }^{15}$

$10 \quad$ Ifatti e prodezze, SATHAS VIII: canto 1, no. 5, p. 473, interpreting Blessis' origin in Venetian Neapolis (today Nauplion) on the Peloponnese, at the time of the song's reference already in Ottoman hands. For the stratiot struggle for their own home, La pressa di Nicosia, SATHAS VIII: no. 38, p. 266 ( $i$ nostri spithi).

11 This view of patriotism is today considered mostly the projection of so-called "patriotic Humanism" that was originally defined by the Florentine theorists of the so-called "second" and "third" generation of Humanists (e.g. Niccolò Machiavelli), calling for concrete civic action as inspired by the quest of the old Guelph nobility to "protect" the city and Catholicism from imperial power; as such, it was different from the general, apolitical patriotism projected earlier by Petrarch and his immediate followers. In Venice, the patriotism of the time was fixed on the city's political centrality, highlighting the Republic's need to protect its supreme power over its maritime possessions. On Venetian patriotism, LIBBY JR. 1978: 103-126.

12 Usually, the Peloponnese in this poetry is given priority over certain other parts of the Greek world, thus reflecting, in addition to the soldiers' origins, also the political and strategic significance of the place in the latter part of the $15^{\text {th }}$ and first part of the $16^{\text {th }} \mathrm{c}$., when the popes and the Republic of Venice attempted to challenge the Ottomans there and restore the Byzantine imperial throne that would be under their suzerainty.

13 Sopra la pressa di Margaritin, SATHAS VIII: p. 470: chal vol turnar to terra Custadina; La pressa di Nicosia, SATHAS IX: no. 46, p. 266. Cf. Tarchaniota, SATHAS VIII: v. 340-345, p. 599. SULTAN 1999: 67-73.

14 For a more detailed analysis of some of these views, LAMMERS 2015: 206-269.

15 I fatti e prodezze, SATHAS VIII: canto 3, no. 44, p. 490; ibid. no. 64, p. 499: Del mazar tante bestie cul mie man. The identification of the Ottomans with the heretical Patarenes, racially belittled for their origin (zigante Patarin), can be found in I fatti e prodezze, SATHAS VIII: 
breaking their ancestral bonds, and turning each stratiot into a foreign wandering warrior (similar to the archaic hero $\xi \dot{\varepsilon} v o \varsigma$ ),${ }^{16}$ whose actions require campaigns of vengeance, but, even more importantly - restoration.

Molino's idea of restoring the Home/Patria from its present "unhappiness" and Ottoman "slavery" is largely visible in his use of ruptures that inherently give the stratiot Home more special meanings. Ruptures, to use the common term, are important devices in any mnemonic mediation, since they show a clear break between one's past and present, the so-called zero moment. ${ }^{17}$ In "real" refugee narratives, the zero moment is often presented as a swift instant of time that describes the transition (the so-called "passage") between the "old" and "new" life, often a tragically depicted event (commonly articulated as an impersonal "this evil") in which the refugees lose their home or loved ones, to start a "new" life that is seen as involuntary (permanent) exile and hence unwanted violent detachment from their past selves. ${ }^{18}$ Unlike these accounts, Molino's poetry transfers the soldiers' past to their present by detailed reference to their military campaigns and conflicts. In this process, the new homes for the stratiots are mentioned as functioning on the Italian territories, but having a temporary (seasonal) character as places of refuge that provide the stratiots with safety - but not a sense of belonging! - until their Patria (Constantinople) is restored. ${ }^{19}$

Molino created a more elaborate rupture in his reference to the ancestral faith of the soldiers, Orthodox Christianity. His plays present this religious denomination as the part of their core being, but qualify it also as an "erroneous" and "sinful" part of their past and, sometimes, even the primary cause of their Home's "fall" (exegetically seen as "sin") and their subsequent émigré misfortunes. ${ }^{20}$ Such an interpretation of the soldiers' faith largely coincides in time with the debates about the Christian unity developed between the Council of Florence (1439) and the Council of Trent (1545-1563) that imposed Roman Catholicism over other

canto 4, no. 55, p. 504; La pressa di Nicosia, SATHAS vol. VIII: no. 43, p. 266; Sopra la pressa di Margaritin, SATHAS VIII: 467: le parenti chi restadi Greghi vivi in campo nostro to allo chrono/ (bold henceforth denoting the stress italicized in Sathas' edition of Molino's verses); cf. Gemistos, SATHAS VIII: caput 2, v. 1, p. 553. The notion of enslavement of citizens by tyrants is clearly influenced by common Humanist interpretations of Plato's politeia, as well as the general Humanist perception of archaic poetry that, in its broader sense, stressed the heroic ethos and the function of military participants in what was seen as their civic "constitution" and identity.

16 Sultan 1999: 12-23. It is important to note that Molino used the Greek language to refer to the past, thus obviously stressing its mnemonic character.

17 DESEURE AND POLLMANN: 2013: 315-329.

18 La pressa di Nicosia, SATHAS VIII: no. 29, p. 265.

19 La pressa di Nicosia, SATHAS IX: no. 41, p. 266; no. 18, p. 264; IBID., no. 41, p. 266: Passado il chimona/torneremo al chalochieri/ con la sindroffia si bona/ de cavalli e archibussieri,/ palikari e bon guerieri/, como fò l'nostri vecchietti.

20 Cf. Tarchaniota for his expressions of inculpation, SATHAS VIII: vv. 335-340, p. 599. 
interpretations of Christianity in the European West, so there is no doubt that Molino's insinuations about the sinful error and heavenly guilt (culpa celesta) of the stratiots reflect the wider religious policy of the Roman Catholic church proposing a "remedy" that conditioned the stratiots to accept the Roman Catholic interpretation of the Filioque definition, and, together with it, the supremacy of the pope in Rome. ${ }^{21}$ Such a resolution of the long-term rift between the Orthodox East and Roman Catholic West was indeed favoured and propagated by the Roman popes of this period, while its practical implementation was particularly systematic in the territories controlled by the Republic of Venice, especially in the eastern Adriatic and Greece, where most of the Serenissima's subjects during the $16^{\text {th }}$ and the $17^{\text {th }}$ centuries were indeed Orthodox Christian. The Venetian aspiration to lead its Orthodox subjects into the Christian union is particularly stressed in Molino's comedies that, on the one hand, openly mock and ridicule the Orthodox cults of the stratiots, celebrate, on the other hand, these soldiers as the champions of "unity in faith," and projecting their image as the "new generation" of Crusading warriors, worthy of defending their "new" homes administered by the Republic of Venice. ${ }^{22}$ This ambiguous "novelty" introduces another rupture in Molino's poetry: the emotional swing from the usual pessimism and concern of Byzantine émigrés ${ }^{23}$ to stratiot optimism and exaltation of the present, marked by their remembrance of their glorious and joyful moments in combat. ${ }^{24}$

$\overline{21}$ La pressa di Margaritone, SATHAS VIII: p. 469: papa [...] perduna l'piccao del christian stelo. The views of Orthodox "errors" and ancestral sin as the causes of the "Fall" of the Byzantine East were articulated particularly well in 1439, when Cardinal Bessarion exposed the papal project of Orthodox union to the Greek delegation at the Council of Florence, offering the Greeks absolution from their "ancestral errors" as a reward for their acceptance of the Roman Catholic formulation of the Holy Trinity (the Filioque formula) and, subsequently, the supremacy of the Roman pontiff, GEANAKOPLOS 1989: 226; 250-251. As noted by PETTA 1996: 26, opposing views of Christianity by the Orthodox and Roman Catholics were frequently mentioned in the popular theatre and local poetry of the Italian Renaissance that were represented by grotesque figures, such as a giant Margutta, the son of an Italian abbess and a Greek priest, or, a Baldus del Folengo, nicknamed Pizzacapelleto, the son of a Greek father and a Calabrese mother: barrus, giottus, latro, fur, furca, trufator/Quid restat? Stradiotus erat, queo dicere perggium?/Sed quia per guerras stradiotica as semper usanza est/Ferre scaramuzzas aut appizzare baruffas/Inde attaccatis armis se trare dabandam/Pizzacappelletus seu Pizza Guerra vocatur.

22 Cf. I fatti e prodezze, SATHAS VIII: canto 8, no. 64, p. 541 (e tira un botta da tagiar un raval Grossa como l'Rotonda del Rumani) and La pressa di Nicosia, SATHAS IX: no. 3, 262 (nel bexogna cha moriri/[...]/per San Marco e castigari/sta genia del maneretti). Cf. Tarchaniota, SATHAS VIII: vv. 231-240, p. 597, where the Crusaders were equated with the Spartans of the Greco-Persian wars, and IBID.: v. 269, p. 598, describing this fight as beautiful (certamine pulchro); also, cf. Gemistos, SATHAS VIII: caput 3, vv. 25-284, pp. 559-564. SETTON, HAZARD AND ZAKOUR 1969: 311-353.

For the depressing tone of émigré poetry, cf. Gemistos, SATHAS VIII: caput 4, vv. 95 - 99, p. 566.

Sopra la pressa di Margaritin, SATHAS VIII: 470. Cf. Gemistos, SATHAS VIII: caput 1, vv. 85-99, p. 548. 
Commemorated in this way, the conflict between the stratiots and the Ottomans becomes a Humanist Apocalypse - the ultimate combat in which the "Turks" lose their heads in a wind's blow, while the heavens are moved and trumpets can be heard. ${ }^{25}$ Importantly, the stratiots of this Apocalypse are all presented as young and skilled warriors of archaic Greek poetry (palikari, synthrophia, Greciae iuvents), who need to die (bisogna muriri) a quick death that leads them to martyrdom and eternity. ${ }^{26}$ In such a battle, the arduous military labours of the stratiots are transformed into a Renaissance turba (turmoil) that equates them with medieval Roland, Ariosto's mad Orlando - or even the Devil! ${ }^{27}$ Their capacity for this kind of battle is additionally underscored by Molino's frequent mention of their military gear, their skills (cavaller nuvello) and the latest technologies they use (Nostri Greghi sono forniti dei cavalli e ronchetti, spade e bombarde), also encompassing naval warfare, which, in real life, was still a novelty for many stratiots even after the Battle of Lepanto (1571). ${ }^{28}$ Thus accomplished victories bring biblical Salvation to the stratiots, and their consequent benediction and sanctity. ${ }^{29}$ As in any other Humanistically intoned narrative on military combat, the stratiot turbae recounted by Molino eventually lead to revolutionary change: the moment in which the soldiers' (old, Byzantine) Home/Patria re-emerges from the debris of Ottoman destruction, to lay down the foundations of a new Home/

25 At the introduction of the Balzeletta, Sultan Selim II is referred to as the "last King of the Turks" challenging the stratiots with naval confrontations; I fatti e prodezze, SATHAS VIII: canto 2, no. 44, p. 484. Cf. Gemistos, SATHAS VIII: caput VI, p. 583-584.

26 SULTAN 1999: 67-73. The stratiots are, significantly, all considered young (palikari), thus replicating the archaic notion of Greek warriors as young and unmarried, bound to their military units by commensality (syntrophia). In Balzeletta (and, similarly, in La pressa di Nicosia), Molino repeated this notion at the beginning and end of his songs, also Latinising it as Greciae iuventus.

27 I fatti e prodezze, SATHAS VIII: canto 1, no. 1, p. 473: Le Rinaldesche e l'Urlandesche. For the terminology and other tools used to highlight the ferocity of these fights, see IBID.: canto 3, nos. 38-43, 490 (grigora, pieno della colera ...); IBID.: canto 8, no. 33, 523; La pressa di Nicosia, SATHAS IX: no. 33, 265; no. 122, 273; La pressa di Margaritone, SATHAS VIII: 469. The identification of stratiots with the Devil here reflects Humanist projections of the Devil as a familiar and not-so-feared, but rather villainous character, characterized by remarkable physical strength and military capacity inherited from the Homeric pagan (non-Christian) heroes, hence of "diabolical" nature (cf. Luke 10:18).

28 I fatti e prodezze, SATHAS VIII: canto 1, no. 25, 475. La Barzeletta, SATHAS VIII: nos. 7-8, 461. Molino's poetry remarkably noted a variety of prosaic matters concerning the stratiots, such as their relations with women (I fatti e prodezze, SATHAS VIII: canto 2, no. 59, 486: hunur del sexo feminile), their violent behaviour (IBID.: canto 3, 65-66; 2, 52, 485: Chio presto el fa pissar senza urinada) or their perceptions of food (e.g. I fatti e prodezze, SATHAS VIII: canto 1, no. 16, p. 474: Frisca como psomi chie viene dal forno), all issues common in the secular discourse of the time, but rarely expressed in intellectual or sacral works.

29 La pressa di Nicosia, SATHAS VIII: no. 95, p. 271. 
Patria for the stratiots under Venetian rule. ${ }^{30}$ This moment allows their past to continue to live in their present, but it also hints at an even more important political assertion: the long-term claim of the Republic of Venice to the legacy of the Byzantine imperial throne. ${ }^{31}$ As is commonly known, throughout the Middle Ages, the Byzantine Empire was seen as the continuation of the universal Roman Empire, which can further explain the highlights of Molino's poetry about the stratiot past seen as a family, with Byzantium and its Roman legacy representing their old Home/Fatherland, juxtaposed against the common "colonial" perception of the Republic of Venice and its place as the soldiers' metropolis, their new Home/Motherland. ${ }^{32}$ These highlights cannot be found in the poetry's reference the stratiots' real homes that are designated with the term Hellada, thus referring to the Greek territories in the Peloponnese, Ionian islands and the Aegean. When describing these territories under Venetian rule, Molino's stratiot verses resort to Plato's notion of $\pi \mathrm{o} \lambda \imath \tau \varepsilon i ́ \alpha$ and its Roman/Humanist Latin interpretation as free and independent civitas/res publica, thereby highlighting the independent status of the Republic of Venice as their formal suzerain, while also simultaneouly keeping it in the general Christian context (cf. Acts 22:28), obviously in order to signal the proximity of the stratiots to the Venetian Republic and Catholicism ( $I$ nostri Veneziani). ${ }^{33}$ During the first Venetian war with the Ottomans (1463-1479), some of these Greek territories (e.g. Negroponte) had already been taken by the Ottomans, which necessitated future comprehensive military campaigns that the Republic of Venice would organise to "liberate" them, thus keeping the stratiot idea of the restoration topical for the next two hundred years. ${ }^{34}$

30 In Sopra la pressa di Margaritin, SATHAS VIII: p. 469. In Balzeletta, SATHAS VIII, no. 4, p. 461 , this change is qualified as a transformation (metamorphosis).

31 These assertions were outright in the Venetian activities around the Fourth Crusade and the subsequent conquest of Constantinople (1204) by the Latins, as from LAIOU 2005, as well as in the Venetian interpretation of its role in the transfer of the Byzantine imperial legacy after 1453, see NICOL 1988: 124-147; 408-422; HARRIS 2015. As it is widely known, the concept of Christian union did not require a complete conversion of Orthodox Christians to Roman Catholicism, as it allowed them to retain their language and liturgy, as long as they adopted the Catholic interpretation of the Filioque formulation and the supremacy of the Roman pope. More on the nature of the Christian union between the Catholics and the Orthodox, WEBB 1997; SIECIENSKI 2010. A larger view of Venice as a "new land" is also found in Tarchaniota, SATHAS VIII: vv. 215-216, p. 597, and was also acknowledged by Gemistos, SATHAS VIII: caput 3 , v. 173 , p. 562, and book 4, v. 85, p. 566, who acknowledged the Venetian authorities as propugnatores fidei spesque and Christocolae.

32 La pressa di Nicosia, SATHAS VIII: no. 127, 244: un gran Matrona/parentada in Venethia; La pressa di Nicosia, SATHAS VIII: no. 128, p. 274: Roma/che in memoria sarà panda; Gemistos, SATHAS VIII: caput 2, v. 3, p. 553.

33 HARTE AND LANE 2013.

34 La pressa di Nicosia, SATHAS VIII: no. 133, 274-275. As it is commonly known, in 1464 Pope Pius II proclaimed a Crusade that aimed at restoring the Greek Despotate in the Peloponnese 
The concept of the restored Home may have been associated with Constantinople, Greece or Venice, but Molino's verses cited one other place as its centre: Moscow. ${ }^{35}$ At the time, Moscow was the seat of the Grand Duchy that influenced the entire Slavic East and, like Venice, also claimed the Byzantine imperial legacy after 1453. Unlike the Venetian claims that aspired to political control of the exByzantine territories based upon the Republic's share of the Byzantine legacy since the Crusaders' conquest of Constantinople in 1204 (Fourth Crusade), Moscow's claims were attached to a genuine member of the Byzantine ruling dynasty (the Palaiologoi) - Zoe, the daughter of the Despot Thomas Palaiologos, who, having been married to Grand Duke Ivan III (1462-1505), transferred her family's ruling legacy to her husband and their offspring. Thus the Grand Dukes of Moscow could claim that they were not only the protectors of the Orthodox in Moscow, but also of all other Orthodox Christians, which further explains why the main characters of Molino's poetry apparently celebrate Moscow as the New Jerusalem, glorifying its military resources (castro bello e forte) but mocking, in fact, the Duchy's actual defeats by the "enemies of Christianity" (the burning of Moscow by the Tatars in 1571). At the same time, Moscow held a high place in Venetian political considerations due to its claims to the Polish throne, which were an issue in Europe's wider political constellation just prior to Venice's confrontation with the Ottomans; hence by connecting Moscow to the stratiots loyal to Venice, Molino's verses also reflected the Republic's immediate political and military concerns about its foes and allies for the "holy" war it aspired to lead as of $1570 .{ }^{36}$

The processes of memory transmission and its preservation are important prerequisites for any memorial culture; hence, their accounts often tend to balance devices that mediate the effects of ruptures. In Molino's poetry, the most effective one is his induction of strong emotions. In some of Molino's stratiot poems, these emotions project pain, most often connecting the stratiots with the tragic loss of their old Home/Patria, or some actual defeat of their military campaigns. ${ }^{37}$ Other

(Morea) on behalf of his favourite "Hellene," Thomas Palaiologos (brother of Emperor Constantine XI Dragases and Despot of Morea until 1460). For an instructive account about the subsequent Venetian campaigns against the Ottomans, DAVIES AND DAVIS 2007.

35 Sopra la pressa di Margaritin, SATHAS VIII: no. 8, p. 463.

36 STREMOULOFF 1953: 84-101; SETTON 1984: 1087; ROGERSON 2009. The tendency of Greek and other Balkan soldiers to relocate to Russia is apparent especially in the $18^{\text {th }}$-century Kingdom of Naples, but also in Habsburg Central Europe which, after the military defeats of the Ottoman army during the latter half of the $17^{\text {th }}$ and first half of the $18^{\text {th }}$ century, significantly tended to decrease and demilitarise the areas that had previously served as their borders with the Ottomans.

37 In some Humanist poems, one finds mention of tears in connection with the pain for the soldiers' military defeats, e.g. Gemistos, SATHAS VIII: vv. 85-99, p. 548 (similarly, the presentation of the Fall of Constantinople by Greek Cardinal Bessarion at the Congress of Mantua, 1459/1460, 
highlighted emotions are the desire for revenge, and their penitence for the sins and "errors" of their ancestors. ${ }^{38}$ Among some more positive feelings of Molino's verses one finds hope and joy, both in connection to the Crusading activities of the stratiots and the idea of their Home's restoration, usually standing juxtaposed with the emotions of pain and loss, thus buffering the negative outcomes of the accounted events, particularly their losses in the battlefield. ${ }^{39}$ Other tools by which this poetry mediated ruptures were the usual devices which Humanists of the time borrowed from classical rhetoric, among which, the most frequent were exclamations, repeated phrases and questions, imagined dialogues and dramatic pictures of motion (the heavens moving) and sound (music, good news usually announced with trumpets). ${ }^{40}$

The old and new realities of the stratiots are well balanced by Molino's language as well. While lofty Humanist poems of his time used elaborate Neo-Latin and its devices that transformed Greek culture into the Humanist Latinitas, Molino's verses were created in a hybrid called gregescho, in which he mixed the vulgar Venetian dialect with demotic Greek, skilfully imitating the daily communication of Venice's Greek subjects, but also stressing their common errors in speaking the Italian vernacular (ena nicta; Copse a chesto to keffali, kaci spera, chrogni eneninda) ${ }^{41}$ Some of the terms in these expressions are highlighted, however, and they always appear in their consistent correct forms in the Greek language. Among the most frequent such terms are religious expressions denoting God and Christ (Theos, Christos), put along the Humanist highlights of Fortuna and figures of the Roman and Greek Pantheons; other forms hint at Molino's tentative plays with ambiguous meanings (esp. plio). ${ }^{42}$ Importantly, while these forms are gram-

VAST 1878: 238-241). In other Humanist poems (e.g. Marullus' reference to Euxinus et lacrimae), the "use" of tears clearly refers to Ovid's notion of exile (LAMMERS: 206).

467, where Molino placed the Christian divine forces above the classical Musae: girise l'musa apano e là el Segnor regratiando. For an example of an invented dialogue (a common rhetorical device of the Humanists), Sopra la pressa di Margaritin, SATHAS VIII: p. 468; I fatti e le prodezze, SATHAS VIII: canto 7, no. 34, p. 516. La Balzeletta, SATHAS VIII: no. 12, p. 462 (bre, bre, bre).

41 E.g. Balzeletta, SATHAS VIII: no. 35, p. 464. La pressa di Nicosia, SATHAS IX: no. 118, p. 273. EINSTEIN 1946: 19-32; SALA 1950-1951: 141-188; SALA 1951-1952: 291-343.

42 Sopra la pressa di Margaritin, SATHAS VIII: p. 469; La Balzeletta, SATHAS VIII: nos. 47 and 49, p. 465; La pressa di Nicosia, SATHAS VIII: no. 20, p. 264; no. 46, p. 266. In all of Molino's works, particularly interesting is the use of the term plio. While its context clearly points out that it was used as an adverb forming descriptive comparisons (Greek $\pi 10 /$ Italian più/Latin plus), its form in Molino's poetry implies the verb $\pi \lambda \varepsilon \dot{\varepsilon} \omega$ (navigate) that is the part of the apostolic vocabulary (Acts XXVII, 37; Luke, V, 37) and its subsequent Crusading context of the "passagium." Molino's similar wordplay can be also found in La pressa di Margaritone, 
matically correct, their connotation stresses the Latin/Catholic interpretation of the Christian union that insisted on the supremacy of the pope and the political power of the Republic of Venice. ${ }^{43}$

A comparison of Molino's stratiot poetry with other pieces of exile poetry relating to the post-1453 Byzantine émigrés further highlights the importance which Molino accorded to the Catholic-Orthodox union and adherence to it by (mostly) Greek stratiots who served the Republic of Venice. The songs of Albanian stratiots from Southern Italy, orally transmitted by their communities for several generations until the $19^{\text {th }}$ century, when they were published by A. Scura, have, for instance, a significantly different form and message. They are substantially longer than Molino's pieces, and they largely use the Albanian language (Italian translations provided here were made by their publisher, A. Scura), thus suggesting that they were circulated within a narrower community of stratiots and their émigré compatriots. Furthermore, their content puts more stress on the soldiers' refugee status and effects of their "exile," while the glory of their fights and the soldiers' aspirations for the restoration are rarely mentioned. ${ }^{44}$ In these songs, Albanian stratiots fight the Ottomans in foggy, distant and hardly accessible mountainous realms of their ancestors' homes across the Adriatic. ${ }^{45}$ This fight requires the crossing (passagium) of the sea, but is far from any Crusade, the Humanist views of the Patria lost, or any reference to the exegetic points of their return. Similar to Rallo's poetry that highlights the effects of the Home's loss, the painful awareness of Albanian soldiers about their irrevocably lost ancestral homes is the most dominant emotion of this entire cycle. ${ }^{46}$ Their most significant rupture is placed in the historical moment of the loss of their homes (Addio, per sempre adio! Terra natia,/ terra di patri miei che lieta amai/salve, ch'io ti abandono o patria mia/ o patria mia, non te vedro più mai!), or in the death of their leader, George Castrioti Scanderbeg (d. 17 January 1468), whose alliance with Aragon King Alphonso V in Naples (1442-1458) brought some Albanian groups to Southern Italy during the 1450s

SATHAS VIII: 467, where he uses the Italian term Chiesa to denote a church building, but its

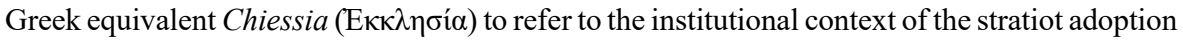
of the Christian union, e.g.: Sui mondo allo pagano/no plio commandera, mo ti el Signore/sarà d'una clissia, e d'un pastore.

43 Sopra la pressa di Margaritin, SATHAS VIII: 469: Credo l'Curner, Querin, Canal [...]; cf. Tarchaniota, SATHAS VIII: vv. 250-256, p. 597. Gemistos, SATHAS VIII: caput 1, vv. 99-118, 548; and IBID., p. 568, calling the Roman pontiff a "liberating shepherd." Nichols 2010.

44 La pressa di Nicosia, SATHAS IX: nos. 134-135, p. 275.

45 SCURA 1912: book 1, no. 3, p. 141; no. 4, p. 144; no. 5, p. 146. For their attitude on war, most directly, IBID.: book 30, pp. 203-211 and book 2, vv. 1-5, pp. 211-223.

46 IBID: book 2, no. 22, p. 265; no. 30, 283; ibid., book 3, no. 31, p. 283: Profugi orphanelli, thus equaling the loss of the soldiers' native land with the loss of their family (the entre song recounts the breaking of their ancestral ties); these songs take Naples (i.e. Kingdom of Naples) as their "real" home SCURA 1912: book 2, no. 26, p. 273. 
and early $1460 \mathrm{~s} .{ }^{47}$ Scanderbeg's death - he was specially praised as a Crusading hero by Pope Pius II (1458-1464) - imbued the songs of Albanian stratiots with depression and laments about their poor prospects and lack of a bright future. Their new homes on Italian soil were not seen as "us/ours", but rather the places of the stratiots" "forced" belonging to the incomprehensible Other, in which the soldiers and their families felt discomfort and isolation (scesi nei estranei liti). ${ }^{48}$ The Albanian stratiots mentioned in these songs still go to war and fight fiercely, but only when they are summoned by conscription (...il sovrano/ha già fatto l'appello/seguir dovrò le schielle), and waging it in an unruly and undisciplined way, giving little notice to the strategy or new technologies. There is no holy or elevated Humanist emotion in these songs (lascia me pugnar con questo cane), although some hints about the Crusading nature of these soldiers' fights might be found (...cavallo mio nel vasto agone/al mio signore e a me farai tu onore), while the soldiers' immediate protection of their families and honour are stressed as their primary motives. ${ }^{49}$

In another comparable tradition, the uskoci poetry based on Slavic peasantsoldiers originating from the hinterland of today's Montenegro and Herzegovina and settling in the Venetian territories in the Eastern Adriatic (today's Croatia) after fleeing the Ottomans, the émigré soldiers are celebrated for their frequent crossing of the Venetian borders to challenge the Ottoman governors and their subjects with a tactics of swift attack and withdrawal, in guerrilla-like conditions. The fight of the uskoci was widely labelled a Crusade, and there is stress on the generational change in their "conquest" of Ottoman territory in which the uskoci are seen as young fighters assuming the tradition of their elders (similarly as according to the ancient Greek concept of $\kappa \lambda \dot{\varepsilon}$ os), yet their poetry, similar to that of the Albanian stratiots in Southern Italy, is more closely focused on the soldiers' immediate communities and personal honour. ${ }^{50}$ It circulated in the local Slavic dialect common to

47 MONTI 1939: 121-184. Some of these songs are centred in Scanderbeg's life, but also his death, SCURA 1912: book 8, pp. 229-247; 249; IBID.: pp. 255-259, projecting strong emotions of loss when evoking Scanderbeg's end.

48 SCURA 1912: book 2, no. 31, p. 283: le straniere donne/in sembiante lieto/accorreranno per vedere i profughi; ibid.: un affetto segreto/ai peregrini in cuore. By the $1530 \mathrm{~s}$, when some groups of Hellenised Albanians from the Peloponnese began to appear in the Kingdom of Naples, a negative attitude toward Eastern refugees had already developed among the local population, who demanded their expulsion from urban areas, justifying it by the number of real or imagine incidents which the newcomers allegedly provoked against the locals, and their segregation to the isolated mountains of Calabria, where, today, several dozen villages of Albanian (Arbërësh) tradition still exist.

SCURA 1912: book 2, no. 12, p. 242, for commensality and spiritual bonding between the two heroes: Pranzavan da fratelli in compagnia/[...] Scander e Milo Schino [...]; likewise Molino's Greek stratiots, Albanian soldiers from the South are also seen in these songs as young. On their specific way of fighting (legère, partisan style) see SCURA 1912: book 2, no. 8, pp. 229-231; IBID.: no. 4, p. 219. For family protection as their motive, see the song about Constantine and his bride in SCURA 1912: book 1, no. 22, p. 175; book 1, no. 30, pp. 203-207.

50 LONGWORTH 1979: 348-368. 
the stratiots and their families, usually sung with gusle (a single-string instrument used by the Balkan peoples, especially those who lived in the mountainous areas of the Dinaric mountains) and structured in the epic decasyllable. Unlike the sombre songs of the Albanian stratiots in the Italian South, this poetry, however, stresses the soldiers' optimistic attitude towards their new Home, rarely mentioning their old homes as places of origin, and showing the uskoci and their families as moreor-less satisfied subjects of the Republic of Venice. A life of plenty (of vineyards and arable land, specifically), the stability of the Serenissima's protection and fighting the Ottomans to accomplish "moral justice," defending the honour of their "name" (clan) and freedom from the Ottoman oppression, stand out as the main frames of this poetry's memoryscape..$^{51}$

Why, then, did Molino project his picture of stratiots as strange and clumsy soldiers deeply attached to their past, but also to their present and future in Venice that they were to defend while propagating the Serenissima's political ambitions in the East? This question cannot be answered with complete certainty, namely because of Molino's genre and the diverse tastes of his mass audience. Still, the fact that Molino's gregescho poetry was particularly popular in the 1560s until 1570, when Venice was on the eve of entering a new war against the Ottomans in the eastern Mediterranean (over Cyprus, 1570-1573) ${ }^{52}$ together with other European Christian powers (the Holy League), brings us to one special detail the fact that, apart from the masses, this poetry was presented to an audience that dealt with literary/theatre writing and its propaganda. This audience formed the core of the Venetian cultural, Humanist elite, but was also highly patriotic and receptive to the Signoria's anti-Ottoman discourse. Molino's salon formed a circle of approximately 20 composers and literary writers who must have understood Molino's sophisticated allusions to Catullus and Ovid, or even the new scholarship of the time (astronomy) quite well, but were also well aware of the glorification of the conflict against the Ottomans highly stressed in his gregesche. In this circle, one person was particularly prominent, and seemingly exceptionally interested in Molino's stratiot poetry - Domenico Venier (1517-1582), a Venetian noble involved in state administration, but also a man of taste and money, who actively contributed to the literature created in Venice's Santa Maria Formosa circle. ${ }^{53}$

$\overline{51}$ Interestingly, the plot of the uskoci song on the Slavery of Stojan Janković and the Albanian traditional songs about the heroism of Constantine show similarities in their reference to the motif of the hero's return home - they both exhibit the same chronological cycles of 9 years of the hero's absence in war (unlike the Odyssey, which involved a naval periplous that lasted ten years, in addition to the initial ten years of Odysseus' warfare at Troy), the new marriages of their wives, and their annulment at the wedding parties by the immediate intervention of the returning soldiers, hence heroes.

52 SETTON 1984; ABULAFIA 2011.

53 On Molino's salon and the potential role of Venier in it, DONELLY 2014: 151-153; 165-169. 
Among all topics and genres, Venier also favoured the patriotic verse, and hence it is not impossible that he stood behind the commissioning of Molino's gregesche, filled with glorification of the Venetian Patria and stratiot heroic "Crusading" fights, in order to have them disseminated to mass audiences as a means of propagating Venice's new anti-Ottoman campaign. ${ }^{54}$ While conclusive evidence of such an arrangement does not exist, there is no doubt that Molino's emphasis on the myth of the Republic's power and prosperity, the sense of belonging to the Republic (the Venezianità) by affirming the Catholic values set forth by the Council of Trent and the loyalty of service to Venice (being a claimant to the Roman imperial legacy) were all "vessels" that may have well enhanced the transformation of the Greek stratiots from obscure foreign mercenaries to diligent defenders of Venetian civic identity and the use of such imagery in the actual Venetian campaigns in the East.

In conclusion, the "stratiot" poetry of Antonio Molino contains diverse places of memory and mnemonic devices reflecting various notions of home associated with Greek stratiot soldiers serving the Republic of Venice. With the reference to their Home as a Patria in need of restoration, its occupation by the Ottomans, but also its corruption by stratiot "errors" of faith and re-emergence through the their "holy" struggle for the Republic of St. Mark, Molino's verses project the image of their voluntary subjection to the Republic of Venice and their adoption of the pontifical model of Christian unity, thus indicating a highly constructed translocal (collective?) memory that exploited the stratiot past not just to entertain his theatre audiences, but also to radiate some more specific political preferences to Venice's Humanist nobility. With these messages incorporated into Molino's idea of Venice as the new stratiot home arising from the debris of the old Byzantine one, this poetry called, in fact, for concrete political and social action that stood high above the alleged diasporic memories of the stratiots and their desire for revenge - the re-formatting of the stratiot identity by affirming their Roman Catholic (Uniate) and Venetian selves, and their use in the current (or future) wars that were to defend and propagate the core values of the Republic of St. Mark. This aim is what makes the stratiots in the verses by Antonio Molino an important instrument in voicing, historicising ("making"), and re-shaping the past of these émigrés and adapting it to the ambitions and needs of their new suzerain.

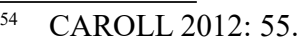




\section{Bibliography}

ABULAFIA, David. 2011. The Great Sea: A Human History of the Mediterranean. Oxford - New York: OUP.

ARBEL, Benjamin, HAMILTON, Bernard, and JACOBY, David. 1989. Latins and Greeks in the Eastern Mediterranean after 1204. London: Cass, etc.

BIRTACHAS, Stathis. 2012. La memoria degli stradioti nella letteratura del tardo Rinascimento. In Tempo, spazio e memoria nella letteratura italiana: Omaggio ad Antonio

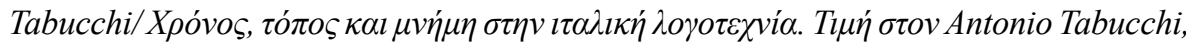
ed. Z. Zografidou. Thessaloniki - Arachne: Aristotle University of Thessaloniki-University Studio Press: 124-142.

BRACEWELL, Catherine Wendy. 1992. The Uskoks of Senj: Piracy, Banditry and the Holy War in the Sixteenth-Century Adriatic. Ithaka, NY: Cornell University Press.

BUGH, Glenn B. 2002. Andrea Gritti and the Greek Stradiots of Venice in the Early 16th Century. Thesaurismata 32: 81-96.

CAROLL, Linda et al. 2012. Delightful Madrigals for Four Voices, etc.( 1568). Rome: Istituto italiano per la storia della musica.

CISILINO, Siro. 1974. Manoli Blessi (Antonio Molin detto il Burchiella): Greghesche, libro primo, 1564. Padova: G. Zambon.

CORTELAZZO, Manlio. 1972. Nuovi contributi alla conoscenza del gregescho. L'Italia dialettale 35: 51-65.

COUTELLE, L. 1971. Gregescho: reéxamen des éléments néo-grecs des textes comiques

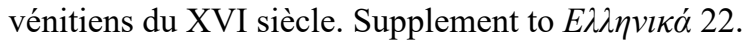

DAVIES, Siriol and DAVIS, Jack L. 2007. Between Venice and Istanbul: Colonial Landscapes in Early Modern Greece. Athens: American School of Classical Studies at Athens.

DESEURE, Brecht and POLLMANN, Judith. 2013. The experience of rupture and the history of memory. In Memory Before Modernity: Practices of Memory in Early-Modern Europe. Eds. E. Kujipers, J. Pollmann, J. Muller and J. van den Steen. Leiden: Brill: 315-329.

DONNELLY, Daniel K. 2014. Cantar à la Venessiana: Venetian language Polyphony in the Secondo Cinquecento. PhD thesis at the McGill University.

EINSTEIN, Alfred. 1946. The Greghesca and the Giustiniana of the Sixteenth Century. Journal of Renaissance and Baroque Music [=Musica Disciplina] 1: 19-32.

FREIST, Dagmar. 2013. In Memory Before Modernity: Practices of Memory in EarlyModern Europe. Eds. E. Kujipers, J. Pollmann, J. Muller and J. van den Steen. Leiden: Brill: 203-221.

GEANAKOPLOS, Deno John. 1989. Constantinople and the West: Essays on the Late Byzantine (Palaeologan) and Italian Renaissances and the Byzantine and Roman Churches. Madison: University of Wisconsin Press.

HARRIS, Jonathan. 2015. The Lost World of Byzantium. New Heaven and London: Yale University Press. 
HARTE, Verity and LANE, Melissa. 2013. Politeia in Greek and Roman Philosophy. Cambridge: CUP.

HASKELL, Yasmin. 1999. The Tristia of a Greek refugee: Michael Marullus and the politics of Latin subjectivity after the fall of Constantinople (1453). The Cambridge classical journal 1: 4: 109-136.

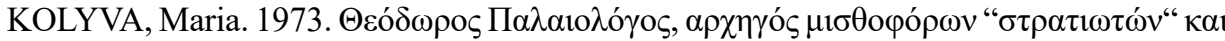

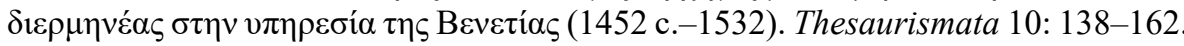

KORONAIOS, Tzanes. 1873/1961. Ex Jannis Coronei Rebus a Mercurio Bua gestis. In Chroniques gréco-romanes inédits ou peu connues publiées avec notes et tables généalogiques. Ed. C. Hopf. Berlin: Weidmann/Athens: 367-370.

LAIOU, Angeliki. 2005. Urbs Capta: the Fourth Crusade and its consequences. Paris: Lethilleux.

LAMMERS, Han. 2015. Greece Reinvented: Transformations of Byzatnine Hellenism in Renaissance Italy. Leiden: Brill.

LAUXTERMANN, Marc D. 2013. Linguistic Encounters: The Presence of Spoken Greek in Sixteenth-Century Venice. In Renaissance Encounters: Greek East and Latin West. Eds. M. S. Brownlee and D. H. Gondicas. Leiden: Brill: 189-207.

LIBBY, Lester J. Jr. 1978. Venetian Views of the Ottoman Empire from the peace of 1503 to the war of Cyprus. The Sixteenth Century Journal 9: 4: 103-126.

LONGWORTH, Philip. 1979. The Senj uskoci reconsidered. The Slavonic and East European Review 57: 3: 348-368.

MADDEN, Thomas F. 2008. The Fourth Crusade: Event, Aftermath, Perceptions. Aldershot: Ashgate and the Society for the Studies of the Crusades and the Latin East, 2008

MONTI, Gennaro Maria. 1939. La spedizione in Puglia di Giorgio Castriota Scanderbeg. Japigia, n. s., X: 121-184.

NICOL, Donald M. 1998. Byzantium and Venice: A Study in Diplomatic and Cultural Relations. Cambridge: CUP, 1988.

NICHOLS, Aiden. 2010. Rome and the Eastern Churches: a study in schism. San Francisco: Ignatius Press.

PETTA, Paolo. 1996. Stradioti: soldati albanesi in Italia (sec. XV-XIX). Lecce: Argo.

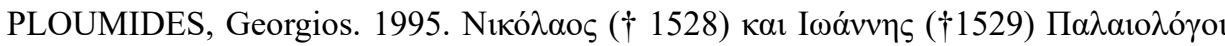
stradioti. Dodone 1: 229-233.

ROGERS, Clifford J. 1995. The Military Revolution Debate: Reading on the Military Transformation of Early Modern Europe. Boulder, Colo.: Westview Press.

ROGERSON, Barnaby. 2009. The Last Crusaders: East, West and the Battle for the Centre of the World. London: Hachette Digital.

ROSSI, Vittorio. Le lettere ai Messer Andrea Calmo. Torino: Loeshcer.

SALA, G. 1950-1951. La lingua degli Stradiotti nelle commedie e nelle poesie dialettali veneziane del sec. XVI. In Atti dell'Istituto Veneto di Scienze, Lettere ed Arti 109: $141-188$. 
SALA, G. 1951-1952. La lingua degli Stradiotti nelle commedie e nelle poesie dialettali veneziane del sec. XVI. In Atti dell'Istituto Veneto di Scienze, Lettere ed Arti 110: 291-343.

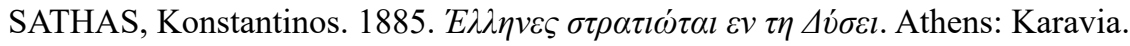

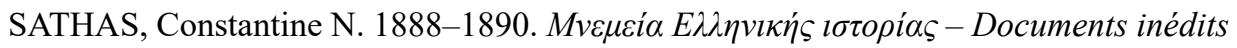
relatifs à l'histoire de la Grèce au moyen âge. Vols. VII, VIII, IX. Paris: Maisoneuve.

SCURA, Antonio. 1912. Gli Albanesi in Italia, e i Loro Canti Tradizionali. New York: Francesco Tocci.

SETTON, Kenneth M. 1969. The Ottoman Turks and the Crusades, 1451-1522. In A History of the Crusades, Vol. VI: The Impact of the Crusades on Europe. Eds. K. M. Setton, H. W. Hazard, and N. P. Zakour. Wisconsin: University of Wisconsin Press: 311-353.

SETTON, Kenneth M. 1984. The Papacy and the Levant (1204-1571). Volume III: The Sixteenth Century to the Reign of Julius III. Philadelphia: The American Philosophical Society.

SIECIENSKI, A. Edward. 2010. The Filioque: History of a Doctrinal Controversy. Oxford: Oxford University Press.

STREMOULOFF, Dimitri. 1853. Moscow, The Third Rome, Sources of the Doctrine. Speculum 18: 84-101.

SULTAN, Nancy. 1999. Exile and the Politics of Loss in Greek Tradition. Lanham-Boulder: Rowman and Littlefield.

TUCCI, H. Zug. 1987. Venezia e i prigionieri di guerra nel Medioevo. Studi Veneziani, n.s., 14: 86-88.

TURNBULL, Stephen. 2006. The Art of Renaissance Warfare: From the Fall of Constantinople to the Thirty Years War. London: Greenhill Books.

VAST, Henri 1878. Le cardinal Bessarion (1403-1472): étude sur la chrétienté et la renaissance vers le milieu du XVe siècle. Paris: Hachette.

WEBB, Eugene. 1997. In Search of the Triune God: the Christian patsh of East and West.

Columbia, MO, University of Missouri Press.

ZEČEVIĆ, Nada. 2016. Memories of Home in the Accounts of the Balkan Refugees from the Ottomans to the Apennine Peninsula ( $15^{\text {th }}-16^{\text {th }}$ centuries $)$. In Vlada Stanković, ed. The Balkans and the Byzantine Wold before and after the Captures of Constantinople, 1204 and 1453. Lanham, Maryland: Lexington Books: 185-198. 


\section{Restauracija, obnova i zajedništvo: sjećanja na dom u stratiotskom pjesništvu Antonija Molina}

U ovome članku razmatra se pojam doma u stratiotskom pjesništvu mletačkog komediografa i skladatelja Antonija Molina iz 16. stoljeća. Ukorijenjeno u životu stratiota i njihovim bitkama protiv Osmanlija, to pjesništvo navodno odražava iseljenička sjećanja grčkih stratiota, premda je očito da je oblikovano samim žanrom te sklonostima Molinove kazališne publike. Ispitujući prostor sjećanja kojim su obuhvaćena poimanja doma što ih je Molino povezivao s grčkim stratiotima kao svojim suvremenicima, ovaj članak razotkriva da se u njegovome pjesništvu zapravo ogledaju opipljivije političke težnje Mletačke Republike da se stratiote s pravoslavlja preobrati na rimokatoličanstvo, ojača njihov mletački identitet, a njihovo sjećanje iskoristi za potrebe vlastitog stremljenja prema bizantskoj imperijalnoj ostavštini, što je sve bilo veoma aktualno uoči mletačkog sukoba s Osmanlijama oko Cipra (1571-1573).

Key words: Greek stratiots, Antonio Molino, Byzantium after Byzantium, poetry of exile, memory of home, Byzantine émigrés in Italy, Christian union, Venetian Renaissance theatre, uses of the past

Ključne riječi: Grčki stratiote, Antonio Molino, Bizant nakon Bizanta, poezija egzila, sjećanje na dom, bizantski iseljenici u Italiji, kršćanska unija, venecijansko renesansno kazalište, korištenja prošlosti

Nada Zečević Centre for the Study of the Balkans Goldsmiths University of London 8 Lewisham Way, New Cross London SE14 6NW, UK E-mail: N.Zecevic@gold.ac.uk 


\section{FILOZOFSKI FAKULTET SVEUČILIŠTA U ZAGREBU \\ ZAVOD ZA HRVATSKU POVIJEST \\ INSTITUTE OF CROATIAN HISTORY \\ INSTITUT FÜR KROATISCHE GESCHICHTE}

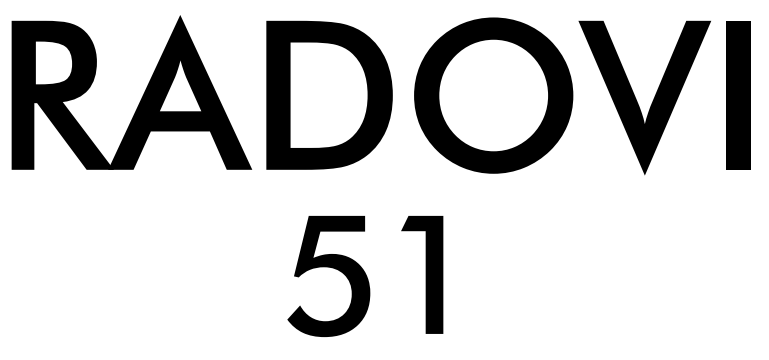

BROJ 1

ZAVOD ZA HRVATSKU POVIJEST

FILOZOFSKOGA FAKULTETA SVEUČILIŠTA U ZAGREBU

\section{FF press}

ZAGREB 2019. 


\section{Poseban broj}

Između Europe i Bliskog istoka: migracije i njihove posljedice na području Jugoistočne Europe $i$

Anadolije u transimperijalnom $i$ interkulturalnom kontekstu

\section{Special issue}

Between Europe and Middle East: Migrations and Their Consequences in Southeast Europe and Anatolia in Transimperial and Intercultural Context 


\title{
RADOVI ZAVODA ZA HRVATSKU POVIJEST FILOZOFSKOGA FAKULTETA SVEUČILIŠTA U ZAGREBU
}

\author{
Knjiga 51, broj 1
}

\author{
Izdavač / Publisher \\ Zavod za hrvatsku povijest \\ Filozofskoga fakulteta Sveučilišta u Zagrebu \\ FF-press \\ Za izdavača / For Publisher \\ Vesna Vlahović Štetić \\ Glavni urednik / Editor-in-Chief \\ Inga Vilogorac Brčić \\ Gostujući urednik / Guest Editor \\ Vjeran Kursar \\ Uredništvo / Editorial Board
}

Jasmina Osterman (stara povijest/ancient history), Trpimir Vedriš (srednji vijek/medieval

history), Hrvoje Petrić (rani novi vijek/early modern history), Željko Holjevac (moderna povijest/

modern history), Tvrtko Jakovina (suvremena povijest/contemporary history), Silvija Pisk

(mikrohistorija i zavičajna povijest/microhistory and local history),

Zrinka Blažević (teorija i metodologija povijesti/theory and methodology of history)

Međunarodno uredničko vijeće / International Editorial Council

Denis Alimov (Sankt Peterburg), Živko Andrijašević (Nikšić), Csaba Békés (Budapest), Rajko

Bratož (Ljubljana), Svetlozar Eldarov (Sofija), Toni Filiposki (Skopje), Aleksandar Fotić

(Beograd), Vladan Gavrilović (Novi Sad), Alojz Ivanišević (Wien),

Egidio Ivetić (Padova), Husnija Kamberović (Sarajevo), Karl Kaser (Graz),

Irina Ognyanova (Sofija), Géza Pálffy (Budapest), Ioan-Aurel Pop (Cluj),

Nade Proeva (Skopje), Alexios Savvides (Kalamata), Vlada Stanković (Beograd),

Ludwig Steindorff (Kiel), Peter Štih (Ljubljana)

Izvršni urednik za tuzemnu i inozemnu razmjenu /

Executive Editor for Publications Exchange

Martin Previšić

Tajnik uredništva / Editorial Board Assistant

Dejan Zadro

Adresa uredništva/Editorial Board address

Zavod za hrvatsku povijest, Filozofski fakultet Zagreb, Ivana Lučića 3, HR-10 000, Zagreb Tel. ++385 (0)1 6120191

Časopis izlazi jedanput godišnje / The Journal is published once a year

Časopis je u digitalnom obliku dostupan na / The Journal in digital form is accessible at

Portal znanstvenih časopisa Republike Hrvatske „Hrčak“ http://hrcak.srce.hr/radovi-zhp

Financijska potpora za tisak časopisa / The Journal is published with the support by Ministarstvo znanosti, obrazovanja i športa Republike Hrvatske

Časopis je indeksiran u sljedećim bazama / The Journal is indexed in the following databases: Directory of Open Access Journals, EBSCO, SCOPUS, ERIH PLUS, Emerging Sources Citation Index - Web of Science 


\title{
Naslovna stranica / Title page by Marko Maraković
}

\section{Grafičko oblikovanje i računalni slog / Graphic design and layout Marko Maraković}

\author{
Lektura / Language editors \\ Samanta Paronić (hrvatski / Croatian) \\ Edward Bosnar (engleski / English)
}

Tisak / Printed by

Tiskara Zelina, Sv. Ivan Zelina

Naklada / Issued

200 primjeraka / 200 copies

Ilustracija na naslovnici

Muza Klio (Alexander S. Murray, Manual of Mythology, London 1898)

Časopis je u digitalnom obliku dostupan na Portalu znanstvenih časopisa Republike Hrvatske ,Hrčak“ http://hrcak.srce.hr/radovi-zhp

The Journal is accessible in digital form at the Hrcak - Portal of scientific journals of Croatia http://hrcak.srce.hr/radovi-zhp 